\title{
Is COVID-19 a Message from Nature?
}

\author{
John Weckert
}

Received: 22 April 2020 / Accepted: 22 April 2020 / Published online: 28 May 2020

(C) Springer Nature B.V. 2020

\begin{abstract}
Claims have been made that the current COVID-19 pandemic is a message from nature to stop exploiting the earth to the extent that we have been. While there is no direct evidence that this pandemic is a result of human actions with respect to the earth, ample evidence exists that deforestation and other environmental changes, together with climate change, do make it more likely that viruses will cross from wildlife to humans. We humans are mammals and our welfare depends on the health of the earth. We are not so different from other living creatures in this regard. It is in our interests to look after the earth, something that Indigenous Australians knew well. Mother Earth must be cared for if she is to care for us. Nature perhaps is sending us a message in the same sense that my car does if I do not maintain it. It stops functioning properly. We have to modify nature to satisfy our needs but we must be careful how we modify it.
\end{abstract}

Keywords Mother Earth · Technology · Respect · Care · Virus $\cdot$ Spillover

We humans are mammals. Even if we believe that we are unique because we are made in God's image, we are still mammals and suffer the same vulnerabilities.

J. Weckert $(\bowtie)$

School of Humanities and Social Sciences, Charles Sturt

University, Wagga Wagga, Australia

e-mail: JWeckert@csu.edu.au
It has been estimated that in the recent fires in Australia, over one billion animals, birds, and reptiles perished, possibly leading to the extinction of some species [1]. The loss of species is not uncommon as environments and climates change. Since the arrival of Europeans in Australia, hundreds of species have become extinct, and many more are under threat [2]. We humans often think that we are special, but Indigenous writer, Tyson Yunkaporta, is not so sure:

Sometimes I wonder if echidnas [Australian egglaying mammals] ever suffer from the same delusion that many humans have, that their species is the intelligent centre of the universe ([3], 1).

This quotation challenges us to also wonder whether echidnas have the same thought about their species. As unlikely as this may seem, the current COVID-19 pandemic sweeping the world should make us wonder whether we are as unique as we like to think. We are part of the natural world just as echidnas are and extinction as a species is as likely for us as it is for others. It is unlikely that this pandemic will be the end of us, but it is not so unlikely that some event or environmental change in the future will lead to our demise. The coronavirus jumped species, coming to us (probably) from bats and possibly via pangolins, so we are not so different in some respects [4].

Recently in a small-town local shop (before most were shut), the elderly lady owner said to me that she thought that humans were a virus on the earth and that now the earth's immune system was fighting back (echoing Attenborough [5]). She was 
referring to the disastrous fires and now COVID19. While this is clearly a metaphor, at one level, it does make some sense, most obvious perhaps in the case of the fires. A prolonged drought and the extreme heat were partly a consequence of climate change and that change is linked to human activity [6]. We have harmed the earth, and now, it is harming us.

How does it fit the current pandemic? According to Inger Andersen, the Executive Director of the UN Environment Programme, "nature is sending us a message" [7] so apparently the metaphor fits quite well but we need to look more closely. Keeping wild animals in close proximity to humans in wet markets played a role (apparently) and that is human doing, but that in itself is not harming the planet in the way that we are influencing climate change. Large populations and lifestyles play a part in its rapid spread but again that is different from the fire case. Nevertheless the metaphor can be a useful way of looking at the problem. The way that we want to live with a global economy and global travel, city living and close contact with other living creatures, whether human or non-human, does come with costs. But the link with human activity seems to be closer, at least according to the media. It is claimed that there is evidence that harming or altering the environment in certain ways raises the probability of viruses crossing species. The conservationist Jane Goodall, for example, reported as saying that "the loss of animal habitats and intensive farming are part of the problem, making it easier for viruses to spread from one animal to another and then to humans" [8]. Many other scientists and environmentalists mentioned in this and other media reports support the view that deforestation and reduction in biodiversity among other factors increase the likelihood of viruses crossing from one species to another, including to humans $[9,10]$. These views are supported by scientific research, not in the case of the current coronavirus (at the time of writing), but the evidence is there in the case of other viruses, particularly the Hendra and Ebola viruses. Loss of habitat through deforestation and fragmentation of forests and climate change can result in movement of species to areas less suitable, higher density, more interaction between different species, and closer contact with humans. This can lead to spillover of viruses to other species including to humans. Animals with higher stress levels are more susceptible to viruses, something that these habitat changes make more likely ([11-16]).
Given the evidence of effects of human activity on the environment, both regarding the fires and virus spillover, even if some of it may be tentative, looking after the natural environment is in the interests of humans, something that of course should be obvious. It is worth taking seriously Andersen's claim that "nature is sending us a message," a claim that presumably would sound like common sense to many Indigenous people, even if not to some like Philip Hammond who see it as "green-hued misanthropy" [17]. His arguments will be considered later, but first, it is worth having a brief look at how Indigenous Australians view the environment, or earth (I am not Indigenous nor an expert in their thought so will largely let them speak for themselves.).

A core belief that has relevance for this discussion is that the earth is a mother. This can be seen in the following quotations from Indigenous Australians:

We call country the mother because as a mother cares for her children so does the land care for us. (Tyrone Bell in [18])

We belong to the land because Mother Earth feeds us and births everything. ([19], 97)

The spirits show themselves in the rocks and trees in natural forms. These spirits come from the land the same as us. The spirit is in that rock, the spirit is in that tree, because it is born from Mother Earth, there's no separation between us. ([19], 121)

The land is the mother and we are of the land; we do not own the land rather the land owns us. The land is our food, our culture, our spirit and our identity. [20]

From this perspective, everything comes from the earth so just as we should love and care for our mothers, so we should love and care for the earth. If we do not, 
the earth will suffer and no longer be able to supply our needs.

You look at the devastating drought [in Australia in the years leading up to 2019], it's a clear indication that mother's sick-we have to show some care for mother and heal her. [21]

From a secular perspective, the central idea is that we depend on the earth for our food and other needs, and if we do not look after it, those needs may no longer be supplied. There is nothing mystical or magical about this. A degraded earth is not conducive to a flourishing life, certainly not for the long term. If we do not look after our car, it will not satisfy our transportation needs for very long. A similar point is made by David Montgomery in his book Dirt, where he argues that environmental degradation has led to the collapse of civilizations (2012).

What, if anything, follows from these musings? Perhaps just that as a species we should not think of ourselves as so different from the rest of nature. We are part of it, and what we do affects it and also us, something that is central to Indigenous thinking but something that modern cultures seem to have forgotten or at least made less important. Looking at things, this way can affect the way that we see technology and its role. We might, and should, start to think more about how our technologies affect the earth. In Indigenous thought, all of nature deserves respect. It is not only people who are worthy of respect, but given the oneness of humans and rest of nature, everything in nature must be respected. Viewed in this way, COVID-19 can be seen as an apocalypse in its original Greek meaning, not as a catastrophe but rather as an unveiling or revelation. It is helping us to realize that we are part of nature and ignore its interests at our peril.

The Spanish philosopher José Ortega Y Gasset [22] defined (or described) technology in terms of nature, and this is a useful way of thinking. According to him technology is

... the improvement brought about on nature by man for the satisfaction of his necessities. (95)

Not being, but well-being, is the fundamental necessity of man... (101)

Therefore the main aim of technology is

To promote good life, well-being, by adapting the medium to the will of the individual. (101)
Technology's purpose then is to enable humans to lead good or satisfying lives by adapting their environment to better suit their needs. Taken as a descriptive account, this fits Indigenous technology as well as it does current technology. According to the observations of early European explorers, the original Australian inhabitants led rich and comfortable lives with little technology compared with the modern world. What they had was ample for their needs.

A problem with this account, certainly if we take it superficially without understanding what a necessity is, is that it leaves open the possibility that "improvements" made to nature to satisfy our necessities may be detrimental to nature in the longer term if we make too many things necessities. Nature could be exploited for shortterm gain to the extent where it will no longer be able to supply necessities in the longer term and, as in the cases of fires and viruses, could actually make life worse for us. This is where the Indigenous standpoint has value. It reminds us to care for nature, or mother earth. We could slightly modify Ortega's account:

to promote good life, well-being, by sustainably adapting the medium to the will of the individual.

... the sustainable modification of nature by man

for the satisfaction of his necessities.

He may have intended this, but now it is more obvious.

To recap, the suggestion in this paper is that disasters such as the fires and the COVID-19 pandemic are signs that we need to be more careful about how we treat nature, "Nature is sending us a message." This view of the pandemic has been expressed multiple times over the past few months, and Philip Hammond mentions many in his criticism of that position [17]. Before commenting on that criticism, we need to be clear on what is being claimed when it is said (including in this paper) that COVID-19 is a wakeup call to humanity. It was noted earlier that seeing the pandemic as the earth's immune system fighting back against the human virus is a metaphor. Another interpretation is that it is similar to treating a person (e.g., our mother) badly so that she no longer wants to help satisfy our needs or that she is unable to because of being damaged. The latter seems to be close to the traditional Indigenous position. A purely secular interpretation, as noted earlier, is that it is like not maintaining our car that we rely on for transport. Eventually it will break down and no longer 
satisfy this need. This is the sense that "Nature is sending us a message" is used here. It is sending us a message in the same sense that the fuel gauge on my car is sending me a message regarding the amount of fuel remaining in the tank. I can disregard it but that would not be sensible.

The claim that nature is sending us a message, according to Hammond, is "to see human ambition to control the natural world as dangerous and deluded." It presents a degraded view of human agency. The argument, not spelt out, is I presume that to suggest that nature is telling us something is to attribute agency to it and thereby suggesting we humans are somehow reduced in importance. It is, he says "a damaging, dispiriting outlook, inviting us to glory in victimhood and vulnerability." It is not obvious however why this is the case. If the fuel gauge tells me that my car is about to run out of fuel, that is a sign that I should use my agency to do something about it, fill the tank. If my farm is no longer productive because I have overworked the soil and it is no longer fertile enough to grow crops, I need to do something about it if I want to continue farming that land. If deforestation or other environment changes make pandemics more common because of the increased likelihood of viruses crossing from nonhumans to humans, then we need to use our agency to remedy the situation if we want to avoid pandemics. How we do this is up to us. It might be by improving the health of the natural environment or by finding technological solutions. Most likely, it will be a combination of both. There is nothing here that projects "a damaging, dispiriting outlook, inviting us to glory in victimhood and vulnerability." We are not victims but rather agents in both the causes and the remedies of the problems. Ignoring this will not promote the well-being of our species or of any other.

To summarize, we are mammals and are vulnerable to environmental changes whether we like it or not, just as all other mammals are, so we need to be aware of the consequences of how we treat nature. We need to be prepared to react to those consequences. The evidence that we are changing the environment in ways that are detrimental to us as well as to other species is strong, for example, by increasing the probability of severe fires or pandemics, but not always obvious at the time changes are made. Thinking of the earth as our mother might be a useful way of keeping a focus on the importance of nature for human well-being and perhaps survival. COVID-19 (and wild fires) can plausibly be seen as messages from nature that all is not well. As Ortega wrote, we can improve nature to better satisfy our needs, but we must be careful how we do this.

\section{References}

1. WWF (2020) World Wildlife Fund: Bush fire emergency. https://www.wwf.org.au/get-involved/bushfireemergency\#gs.46obrq. Accessed 13 May 2020

2. Australian Government (2004) Threatened species and ecological communities in Australia, Australian Government Fact Sheet, https://www.environment.gov. $\mathrm{au} /$ biodiversity/threatened/publications/threatened-speciesand-ecological-communities-australia. Accessed 13 May 2020

3. Yunkaporta T (2019) Sand talk: how indigenous thinking can save the world. Text Publishing, Melbourne

4. Andersen KG, Rambaut A, Lipkin WI, Holmes EC, Garry RF (2020) The proximal origin of SARS-CoV-2. Nat Med 26:450-452. https://doi.org/10.1038/s41591-020-0820-9

5. Attenborough D (2013) Humans are a plague on the earth, Radio Times. https:/www.radiotimes.com/news/2013-0122/david-attenborough-humans-are-a-plague-on-the-earth. Accessed 13 May 2020

6. Climate Council (2020) Infographic: how does climate change affect bushfires?https://www.climatecouncil.org. $\mathrm{au} /$ resources/infographic-how-does-climate-change-affectbushfires/. Accessed 13 May 2020

7. Ghosh A (2020) "UN environment chief warns "nature is sending us a message" through the coronavirus pandemic", Conserve Energy Future. https:/www.conserve-energyfuture.com/un-environment-chief-warns-coronaviruspandemic.php. Accessed 13 May 2020

8. Diprose K, Neal M (2020) Jane Goodall says global disregard for nature brought on coronavirus pandemic, $\mathrm{ABC}$ News, Sat 11 April, https://www.abc.net.au/news/2020-0411/jane-goodall-says-disregard-for-nature-has-broughtcoronavirus/12142246. Accessed 13 May 2020

9. Vidal J (2020) “'Tip of the iceberg': is our destruction of nature responsible for Covid-19?" The Guardian Australian Edition, 18 March. https://www.theguardian. com/environment/2020/mar/18/tip-of-the-iceberg-is-ourdestruction-of-nature-responsible-for-covid-19-aoe. Accessed 13 May 2020

10. DW NEWS (2020) "Virus pandemic linked to destruction of wildlife and world's ecosystems", Bangkok Post, 15 April. https://www.bangkokpost.com/life/social-andlifestyle/1900520/virus-pandemic-linked-to-destruction-ofwildlife-and-worlds-ecosystems. Accessed 13 May 2020

11. Kessler M, Becker D, Peel A, Justice N, Lunn T, Crowley D, et al (2018) Changing resource landscapes and spillover of henipaviruses, Annals of the New York Academy of Sciences. https://doi.org/10.1111/nyas.13910

12. Martin G, Yanez-Arenas C, Chen C, Plowright RK, Webb RJ, Skerratt LF (2018) Climate Change Could Increase the Geographic Extent of Hendra Virus Spillover Risk. EcoHealth. https://doi.org/10.1007/s10393-018-1322-9 
13. Plowright RK, Eby P, Hudson PJ, Smith IL, Westcott D, Bryden WL, Middleton D, Reid PA, McFarlane RA, Martin G, Tabor GM, Skerratt LF, Anderson DL, Crameri G, Quammen D, Jordan D, Freeman P, Wang LF, Epstein JH, Marsh GA, Kung NY, McCallum H (2015) Ecological dynamics of emerging bat virus spillover. Proc R Soc B Biol Sci 282(1798):20142124. https://doi.org/10.1098 $/$ rspb.2014.2124

14. Walsh MG, Wiethoelter A, Haseeb MA (2017) The impact of human population pressure on flying fox niches and the potential consequences for Hendra virus spillover. Sci Rep 7(1):8226. https://doi.org/10.1038/s41598-017-08065-z https:// doi.org/10.1038/s41598-017-08065-zWWF World Wildlife Fund https://www.wwf.org.au/getinvolved/bushfire-emergency\#gs.46obrq. Accessed 13 May 2020

15. Patz JA, Daszak P, Tabor GM, Aguirre AA, Pearl M, Epstein J, Wolfe ND, Kilpatrick AM, Foufopoulos J, Molyneux D, Bradley DJ, Working Group on Land Use Change and Disease Emergence (2004) Unhealthy landscapes: policy recommendations on land use change and infectious disease emergence. Environ Health Perspect 112(10):1092-1098. https://doi.org/10.1289/ehp.6877

16. Redding DW, Atkinson PM, Cunningham AA et al (2019) Impacts of environmental and socio-economic factors on emergence and epidemic potential of Ebola in Africa. Nat Commun 10:4531. https://doi.org/10.1038/s41467-01912499-6
17. Hammond P (2020) "Nature is not sending us a message", Areo. https://areomagazine.com/2020/04/02/nature-is-notsending-us-a-message/. Accessed 13 May 2020

18. Pascoe B (2018) "Mother Earth with Bruce Pascoe," Eric Rolls Memorial Lecture, https://www.nla.gov. $\mathrm{au} /$ stories/audio/mother-earth-with-bruce-pascoe. Accessed 13 May 2020

19. Harrison MD (2013) My People's dreaming: an aboriginal elder speaks on life, land, spirit and forgiveness. Harper Collins Publishers, Sydney

20. Foley (undated) "Connection to Country", https://www. commonground.org.au/learn/connection-to-country. Accessed 13 May 2020

21. Shields M, Gorman M (2019) "Wagga Wagga's first public corroboree since 1870 s honours past, present and country" ABC, 28 Oct. https://www.abc.net.au/news/2019-10-28 /wagga-wagga-corroboree-2019/11644142. Accessed 13 May 2020

22. Ortega Y Gasset J (1961) Man the technician. In: History as a System: And Other Essays Toward a Philosophy of History, translated by Helene Weyl, W. W. Norton \& Company, New York, pp 87-161

Publisher's Note Springer Nature remains neutral with regard to jurisdictional claims in published maps and institutional affiliations. 